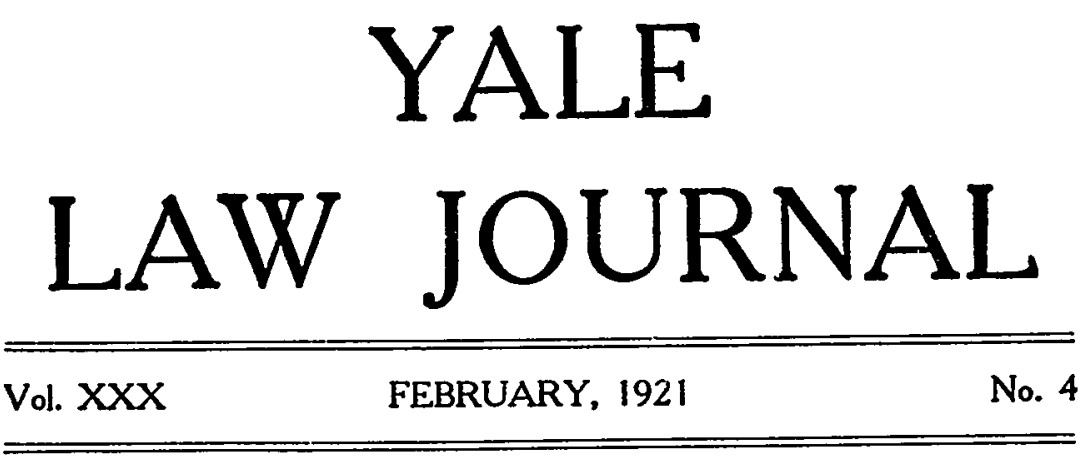

\title{
AMENDING THE FEDERAL CONSTITUTION
}

\author{
W. F. Dopd
}

The recent decisions of the United States Supreme Court in the cases of Hawke v. Smith ${ }^{1}$ and Rhode Island v. Palmer, decide a number of issues as to the construction of the amending clause of the United States Constitution. These decisions, therefore, make it appropriate to review with some fullness the whole procedure for the amendment of the federal Constitution. The decision of the Supreme Court in the case of Rhode Island v. Palmer is of little value standing alone. Justice McKenna agreed with the other members of the Court as to the validity of the Eighteenth Amendment, and in the Court's statement of the grounds for its position. Justice McKenna did, however, think it proper to express a doubt regarding the wisdom of the Court's action in the Rhode Island Case of announcing merely its conclusions, without any argument or reasons in support of such conclusions, and said that such a policy "will undoubtedly decrease the literature of the Court if it does not increase its lucidity."

The mere brief statement of conclusions in the Rhode Island decision means little when taken by itself, but some of the points decided by the Court become clearer if studied in view of the briefs presented in the cases involving the validity of the Eighteenth Amendment. An effort will, therefore, be made in this discussion to sum up the points made by the several briefs, and to indicate the setting of the conclusions expressed by the Court. The case of Hawke v. Smith presents

${ }^{1}$ (Igeo, U. S.) 40 Sup. Ct. 495. The case of Hawke v. Smith is the Court's pronouncement regarding the application of the state referendum to the federal amending process.

' (I920, U. S.) 40 Sup. Ct. 486 . The case here referred to as Rhode Island $v$. Palmer is the Supreme Court's decision in seven cases involving the validity of the Eighteenth Amendment, among them being the cases of Kentucky Distilleries and Warehouse Co. v. Gregory and Feigenspan $v$. Bodine, the briefs in which are referred to below. 
a full review of the issue as to ratification by state legislatures, and it is, therefore, not so necessary to discuss the briefs in connection with the decision in this case.

The briefs presented against the validity of the Eighteenth Amendment are addressed more to what the opposing interests thought ought to be, than to any issues which may properly be termed legal in character. When read, these briefs in many cases seem to be arguments of counsel who were employed to find arguments, and must, therefore, do so, even though they knew the arguments to be untenable. The most effective statements presented to the Court were those submitted in behalf of a number of states as amici curiae, in the cases of Kentucky Distilleries and Warehouse Co. v. Gregory and Rhode Island v. Palmer. These briefs bear the name of Mr. Charles E. Hughes.

Perhaps in no case since that involving the validity of the Income Tax Act of 1894 have historical arguments been so fully employed in the briefs of counsel as in the cases involving the validity of the Eighteenth Amendment. Historical arguments based upon the intent of the framers of the Constitution were frequently urged; and here, as with reference to other points, those seeking to sustain the Amendment had the better of the argument.

Article 5 of the Constitution provides that:

"The Congress, whenever two-thirds of both houses shall deem it necessary, shall propose amendments to this Constitution, or, on the application of the legislatures of two-thirds of the several states, shall call a convention for proposing amendments, which, in either case, shall be valid to all intents and purposes, as part of this Constitution, when ratified by the legislatures of three-fourths of the several states, or by conventions in three-fourths thereof, as the one or the other mode of ratification may be proposed by the Congress: Provided, that no amendment which may be made prior to the year one thousand eight hundred and eight shall in any manner affect the first and fourth clauses in the ninth section of the first Article; and that no state, without its consent, shall be deprived of its equal suffrage in the Senate."

The Constitution provides two methods of proposing amendments and two methods of ratifying amendments, but only one method is here discussed in detail, because it is the only one as yet employed for the purpose of altering the Constitution of the United States.

Extent to which the issues were judicially cognizable. In the cases here under discussion, the contention was first made by those supporting the validity of the Eighteenth Amendment that the issues raised against the Amendment were not judicially cognizable. It was urged that an amendment having been proposed by Congress, and the Secretary of State, under the authority of federal law, having certified that this amendment had been ratified by three-fourths of the states, the issues as to proposal and ratification were not judicially cognizable; and that the political nature of the issue was further strengthened by the fact that Congress had recognized the Eighteenth Amendment 
as a valid part of the Constitution, and had enacted legislation thereunder. It was urged that the issues sought to be presented to the Court in opposition to the Eighteenth Amendment were issues which had been presented to and finally passed upon by the political organs of the United States government. This view is to some extent supported by Jameson's work on Constitutional Conventions, which suggests that

"when the political power has spoken upon the question, the judicial department ought, perhaps, in conformity to the general practice of courts in such cases, to follow its decision."3

On the other side, however, is to be found the unanimous view in state courts that the question as to whether an amendment to a state constitution has been properly adopted, is a question for judicial determination."

The statements in the briefs regarding the judicial power to take cognizance of the issues presented against the validity of the Eighteenth Amendment, are not always clear. The brief for the appellees in the case of Feigenspan v. Bodine, presented by the Solicitor General of the United States, says that it is competent for the Court to determine whether the procedure laid down by the Constitution has been complied with; but suggests that the Court must as to certain questions accept the action of the political departments as conclusive. This brief says further that the political

"branch having determined that the Eighteenth Amendment has been ratified, the courts must accept its decision and the judicial function is merely one of interpretation and application."

Mr. Hughes' brief in the Kentucky Distilleries case argues at length that the question of ratification has been settled by the political departments of the government. ${ }^{8}$ On the other hand, Mr. Elihu Root in the appellant's brief in the case of Feigenspan v. Bodine urged that the questions were properly cognizable by the Court, and said:

"It would certainly be vain for a constitution to. declare or imply limitations upon the power to amend it, if those limitations could be transgressed at will by the very persons who were intended by the people to be restrained and confined within fixed or prescribed limits."7

'J. A. Jameson, A Treatise on Constitutional Conventions (4th ed.) 627. This work is hereafter referred to as "Jameson."

'A further statement of the development in state courts will be found later in this paper.

-Brief for appellee in Feigerspan v. Bodine, at pp. 30-32.

- Brief for the states in Kentucky Distilleries and Warehouse Company $v$. Gregory, at pp. 10-20.

${ }^{7}$ At p. 128. This brief bears the names of Elihu Root, William D. Guthrie, Robert Crain, and Bernard Hershkopf. For brevity it is sometimes referred to hereafter as Mr. Root's brief. 
It may be worth while to review separately the issues which were being presented to the Court in this case, and to discuss separately as to each the arguments bearing upon whether such issues were judicially cognizable. The issues presented to the Court were substantially the following:

(a) Did two-thirds of both houses propose the amendment, and what constitutes two-thirds of both houses? It is quite clear that the Court would not go behind the official record of action by the two houses in order to determine what the two houses had actually done. That is, the official record of the action of Congress would be accepted as conclusive, and no effort to disprove such evidence would be admitted by the Court. This is not an assertion that an issue may not be determined by the Court, but is merely a statement as to the evidence which will be admitted in determining that issue. The real issue is, did two-thirds propose, and what properly constitutes twothirds? This issue, it seems, is clearly one for judicial cognizance, and the Court in passing upon such an issue is merely determining the powers of Congress in the same way that it might determine the powers of the same body to enact legislation. But the proof to be accepted for the determination of the issue is a different matter, and the Court would properly decline to permit evidence to contradict the official records of the two houses.

(b) Is the state's certificate conclusive that there was a proper state ratification under the terms of the Constitution? Mr. Hughes said as to this matter that

"we may assume that the Court would not undertake to go behind the certificate of the action of the legislature in any state in order to determine whether in any particular case votes had been cast for or against the ratification differently from what was disclosed by the certifying authority."8

The issue as to whether the state's certificate of ratification is conclusive divides itself, however, into two parts. One issue is that as to whether the state's certification received and accepted by the political organs of the federal government shall be taken as conclusive of what it says. In this case, as in the case of the records of the two houses of Congress, it may be assumed that the state's certification should be conclusive evidence of what it says. This, however, does not decide the second question, which is, assuming the state's certification to be conclusive of what it says, does the action certified to amount to a ratification by the state? Mr. Hughes apparently realized this distinction, and urged that to pass upon this second point would be to pass upon the structure of the state government, and to decide an issue political in character. ${ }^{2}$ However, it does seem that

\footnotetext{
Brief for the states in Kentucky Distilleries and Warehouse Compary v. Gregory, at p. I9.

Ibid.
} 
the second issue suggested above is properly judicially cognizable, for there can be no effective ratification by a state except through the legislature thereof and there appears to be no distinctly political question necessarily involved in the determination as to whether the legislature is the representative body or includes the referendum.

(c) A third issue involved is that as to whether the certificate of the Secretary of State of the United States under power conferred by statute is itself conclusive of the facts stated in such certificate. This view was expressly urged in the brief of the Solicitor General in the Feigenspan Case, where it was said:

"When an amendment has been, therefore, regularly proposed by Congress, and when the Secretary of State has received official notice that it has been ratified by the required number of legislatures and has proclaimed it to be a part of the Constitution, the political branch of the government has recognized it as a validly adopted amendment and the courts must follow that decision."10

This view, however, seems to be effectively met by Mr. Root's brief for the appellant in the Feigenspan Case:

"By the express declaration of the Constitution, therefore, only an amendment which has actually become such in truth and in law is provided for, and not an amendment which some ministerial or legislative officer believes or declares to have validly become a part of the Constitution. Thus, an amendment which had been duly ratified by the legislatures of three-fourths of the states would automatically become part of the Constitition despite the fact that the Secretary of State might refuse to announce it, because he erroneously believed the ratifications to be defective for some reason. No court would hesitate to disregard his error of law or fact under the circumstances supposed. Likewise, the action of the Secretary of State in proclaiming that an amendment was in effect, when it had not yet been ratified by the requisite number of states, or when it had not yet been ratified by all the houses of the legislature in the requisite number of states, would have to be regarded as a nullity. Any other result would mean that amendments could be made to the Constitution only if. they won the approval of the Secretary of State. Such an interpretation of the fundamental law is plainly erroneous. To refuse an injured party the right to call the action of the Secretary of State into question in the courts, would be, to all practical intents and purposes, refusing to uphold the Constitution and permitting it to be nullified at will by a mere ministerial officer."11

Mr. Root seems clearly correct in his view that it is the ratification of the states that gives effect to a constitutional amendment and not the ministerial function of the Secretary of State in certifying such

\footnotetext{
${ }^{10}$ At p. 3 I.

${ }^{11}$ At p. 132. In United States v. Colby (Igeo, App. D.C.) 265 Fed. 998, the court took the view that the statutory duty of the Secretary of State to proclaim was purely ministerial; and that the approval of the requisite number of states, not the proclamation, brought the amendment into effect.
} 
ratification. The issue here presented seems clearly a cognizable one, though great weight in its determination should, of course, be given to the official record of ratification evidenced by the certificate of the Secretary of State.

(d) The last real issue which was alleged not to be judicially cognizable, was that as to whether Congress had transcended the limits of the Constitution upon the substantive power of proposing amendments. There are, of course, certain express limitations upon the subject matter of amendments which may be proposed, and those opposing the Eighteenth Amendment also urged that there was a number of implied limitations as to the same matter. There was some apparent contention, in support of the Amendment, that the issue so presented was not judicially cognizable, but the real argument was not so much that the limitations on the amending power were beyond review by the Court, as that it would be highly unwise for the Court to extend those limitations by implication so as to cripple the amending power, and to give to the Court in each case a determination without guidance of any rule of law as to whether any amendment might be properly proposed. Those opposing the Amendment were really contending for a discovery by the Court of broad implied limitations upon the amending power, running actually into limitations found in the nature of the government and not at all imposed by the text itself; and those supporting the Amendment took the view that remote implications against the amending power should not be indulged. That is, those supporting the Amendment contended that the Court could enforce against the amending power only the express limitations of the Constitution, and that it would be unwise and improper to discover implied limitations upon this power which would commit to the courts in each case the determination as to the propriety of any amendment, thus forcing the Court into a field really political in character if it adopted such an interpretation of the Constitution. So far as the Constitution imposes limitations upon the subject-matter of proposed amendments, it seems quite clear that the issue is judicially cognizable, and in order to determine whether Congress had transcended such constitutional limitations, the determination as to what are the limitations imposed by the Constitution was properly a judicial question.

The discussion here relates merely to the judicial cognizability of the issue, and later in this paper will be found a discussion of the limits urged by those opposed to the Eighteenth Amendment and properly rejected by the Court. The only issue here is that as to the propriety of the Court's passing upon the issues so presented.

The Court apparently regarded all of the issues suggested above as judicially cognizable, and its decisions (although one of them, without giving reasons) regarded it as proper for it to determine whether the constitutional limits upon the amending power had been observed, and the constitutional methods of proposal and adoption complied with. 
The issue before the Court was, what are the constitutional requirements, and it regarded it as proper to determine that issue, although had it stated reasons, it would probably have limited itself, as indicated above, to the official evidence for the proof of certain facts to be established in determining the legal issues presented.

It may be well to trace briefly the growth of judicial control over the amending process in this country. In Luther v. Borden ${ }^{12}$ Chief Justice Taney said:

"Certainly the question which the plaintiff proposed to raise by the testimony he offered has not heretofore been recognized as a judicial one in any of the state courts. In forming the constitutions of the different states after the Declaration of Independence, and in the various changes and alterations which have since been made, the political department has always determined whether the proposed constitution or amendment was ratified or not by the people, and the judicial power has followed its decision."

State v. McBride ${ }^{13}$ was the first case to assert the judicial power to inquire into the validity of proposed amendments, and here the amendment was upheld, as also in Green v. Weller and Dayton $v$. St. Paul. ${ }^{24}$ Miles v. Bradford ${ }^{15}$ denied the power. Collier v. Frier$\operatorname{son}^{16}$ is the only case before 1880 in which a state constitutional amendment was declared invalid because improperly adopted. Hardly more than half a dozen cases involving the proper adoption of proposed amendments arose before 1880 . Up to 1890 probably not more than twenty such cases had come before the courts. Since 1890 cases have frequently arisen and the state courts have exercised an effective supervision over all steps in the amending process. The brief for the appellant in the Feigenspan Case ${ }^{17}$ suggests that where a court is acting under a constituiion already in force, the court cannot pass upon the validity of that constitution. The brief for the appellant in the Kentucky Distilleries Case ${ }^{18}$ in reply to the contention that arguments made against the Eighteenth Amendment would also defeat earlier amendments judicially recognized as valid, said:

"In response to the argument that the unbroken practice has been to propose amendments by a two-thirds vote of a quorum, it is sufficient to observe that inasmuch as all the states, and the people have, for so many years acquiesced in the amendments it is now too late to question the validity of the method of their adoption."10

\footnotetext{
2 (1849, U. S.) 7 How. I, 39. ${ }^{28}$ (1836) 4 Mo. 303.

${ }^{16}$ (1856) 32 Miss. 65a; (1876) 22 Minn. 400.

${ }^{15}$ (1864) $22 \mathrm{Md}$. 170. See also, Brittle v. People (1872) 2 Neb. 198, 214.

${ }^{20}$ (1854) 24 Ala. I0a ${ }^{17}$ At p. I29. ${ }^{18}$ At p. 30.

" Some state cases uphold the view expressed by Mr. Root and Messrs. Mayer and Bullitt in these briefs. I have discussed the state cases in a book on the Revision and Amendment of State Constitutions (1910) 86-87, 222-226. See also, State v. Starling (1867, S. C.) I5 Rich. Law, r20; and Carpenter v. Cornish (I912) 83 N. J. L. 696, 85 Atl. 240.
} 
Assuming that it is within the province of the Court to enforce the constitutional limitations upon the subject-matter of amendments and upon the methods of proposing and adopting amendments to the Constitution of the United States, we may now proceed to discuss what the limitations are upon both the substantive power and the procedure of amending the Constitution.

Proposal of amendments by the two houses. In the case of Missouri Pacific Ry. v. Kansas, ${ }^{20}$ the Court had before it the question as to what was a compliance with the constitutional provision requiring a vote of two-thirds of each house to pass a bill over the President's veto, and it was held that this provision means two-thirds of a quorum of each house, and not two-thirds of all the members of that body. A majority of the members of each house constitutes a quorum. In considering this question the Court called attention to the identity between the requirement with respect to the overcoming of a veto and that authorizing the submission of constitutional amendments. This issue was, of course, not involved in that case, and it was vigorously urged in the brief for appellant in the Kentucky Distilleries Case that the expression of the Court should not be regarded as conclusive, but that the slightly different phraseology of the amending clause should be made the basis for a difference in judicial view. ${ }^{21}$ This argument was based upon so slight a difference in language as to be pretty clearly untenable, and the Court adhered to the view previously expressed, saying in the case of Rhode Island v. Palmer:

"The two-thirds vote in each house which is required- in proposing an amendment, is a vote of two-thirds of the members presentassuming the presence of a quorum-and not a vote of two-thirds of the entire membership, present and absent."

In the decision of the case of Rhode Island v. Palmer, the Court says:

"The adoption by both houses of Congress, each by a two-thirds vote, of a joint resolution proposing an amendment to the Constitution sufficiently shows that the proposal was deemed necessary by all who voted for it. An express declaration that they regarded it as necessary is not essential. None of the resolutions whereby prior amendments were proposed contained such a declaration."

This statement seems unnecessary, and is hardly understandable, except as read with the briefs in the cases before the Court. The brief for the state of Rhode Island ${ }^{22}$ suggests that the members of the two

* (rorg) 248 U. S. 276, 39 Sup. Ct. 93.

"Brief for appellant in Kentucky Distilleries and Warehouse Co. v. Gregory, p. 16, et seq.

'At p. 97-98. 
houses voting to propose any amendment must deem the adoption of that amendment necessary, and this view intimates the possibility of the Court's being asked to go behind the proposal by the two houses in order to determine whether the members actually voting for a proposed amendment thought that the proposal being voted for was necessary as an amendment to the Constitution. This argument was discussed by the Solicitor General in the Feigenspan Case, ${ }^{23}$ and also by Mr. Hughes in the Kentucky Distilleries Case, ${ }^{24}$ and the argument as presented by the state of Rhode Island was shown to be untenable.

The nature of action by Congress and by the states in proposing an amendment to the Constitution of the United States was fully discussed in the briefs presented in the Eighteenth Amendment cases, and there was much argument to the effect that the congressional function of proposing an amendment and the state function of ratifying are not merely exercises of either national or state legislative power. As a corollary to the view that the proposal of a constitutional amendment is not merely a function of ordinary congressional power as a legislative body, is the view expressed by Justice Chase in the case of Hollingsworth $v$. Virginia:.25

"The negative of the President applies only to the ordinary cases of legislation: he has nothing to do with the proposition or adoption of amendments to the Constitution."

Limitations upon the subject-matter of proposed amendments. The question most vigorously debated in the briefs presented in the cases here under discussion, was that as to the limits imposed by the Constitution itself upon the subject matter of proposed amendments. Article 5 provides

"that no amendment which may be made prior to the year one thousand eight hundred and eight, shall in any manner affect the first and fourth clauses in the ninth section of the first Article; and that no state, without its consent, shall be deprived of its equal suffrage in the Senate."

\footnotetext{
At pp. 67-70.

"In the Kentucky Distilleries and Warehouse Co. brief, at p. 7, Mr. Hughes answered this contention briefly by saying: "It would seem to be a sufficient answer to this contention that the adoption of the joint resolution is in itself an adequate expression by Congress of its judgment in the matter, and that the Court is not at liberty to assume that Congress in passing a joint resolution pursuant to the amending power did not deem the proposed amendment to be necessary."

${ }^{25}$ (1798, U. S.) 3 Dall. 378 . See reference to this statement of Justice Chase in Hawke v. Smith, supro. A full review of the precedents with respect to the President's veto power will be found in H. V. Ames, The Proposed Amendments to the Constitution of the United States during the First Century of Its History (1897) 295; and in Jameson, 586-92. Ames' work will be hereafter referred to merely by the name of the author.
} 
The Constitution thus contained two express limitations upon things that might be done by amendment. One of these limitations expired in 1808 , and the other is still in force.

The prohibition still in force that "no state, without its consent, shall be deprived of its equal suffrage in the Senate," appears clear and definite both in its language and in its purpose. However, it has been urged that this language imposes a much stricter limitation upon the amending power than it seems to imply; and much of the argument implicit in the briefs against the Eighteenth Amendment, seems to be based upon the notion that either the amending clause or the Constitution as a whole, when read with the amending clause, sets up some distinct sphere of state power not subject to alteration by the amending process.

In an article some years ago in the Harvard Law Review, ${ }^{26}$ it was urged that the word "state" as used in Article 5 of the Constitution means the people of the state having political power, and that an increase of such people deprives the state of its equal representation in the Senate. This argument would also deny the validity of the Woman's Suffrage Amendment. The arguments of this article received some support in the congressional debates when the Fifteenth Amendment was being proposed. An even more remote limitation is found in the contention recently made that the provision regarding equal representation guarantees the continued existence of the states, and that this continued existence implies a continuance of powers in the states, which may, therefore, not be withdrawn by a federal amendment having the result of increasing national powers. ${ }^{27}$

Let us turn now from express limitations upon the amending clause to limitations claimed to be derived from the language of the clause itself, although not definitely expressed therein. In favor of the interpretation of the amending clause so as to exclude all implied limitations is the argument that the two express exceptions from the amending power negative the existence of others. The answers to this argument presented in the several briefs are weak, and seek to establish limitations not clearly within the language of the Constitution itself, by strained applications of this language, by remote implications, or by arguments based upon the nature of the federal system.

One set of arguments is that based upon the construction of the word "amendment." Judge M. F. Morris ${ }^{28}$ suggested some years ago that:

"Arthur W. Machen, Jr., Is the Fifteenth Amendment Void? (Igog) 23 HARV. L. REv. 169.

"Justin Du Pratt White, Is There an Eighteenth Amendment? (1920) 54 Ax. L. REV. 245 .

M. F. Morris, The Fifteenth Amendment to the Federal Constitution (I909) I\&g NorTH Ay. REv, 82 
"Amendment may be made and become effective by a vote of threefourths of the states over the objection of the other fourth, or of any number of the states less than one-fourth. Now, addition is something entirely new and not germane to the original instrument: amendment is alteration or improvement of that which in some form is already there. The distinction between addition and amendment is fundamental, and is very clear to every one."

Although Judge Morris' argument is not referred to in any of the briefs, argument upon this point may be practically regarded as in many respects an elaboration of the statement quoted above. The argument that the word "amendment" in itself limits the power of Congress with respect to the proposal of amendments, is most fully presented in the brief of the state of Rhode Island, which urges the analogy of the narrow use of the word in judicial procedure and in parliamentary practice. The argument of the state of Rhode Island is perhaps sufficiently summed up in the following quotation:

"The word 'amendment' is a technical word of common law significance and means simply 'the correction of an error committed in a process.' Amendments are thus limited to the correction of errors committed in the framing of the Constitution." 20

In the brief of the state of Rhode Island a serious effort was also made to limit the construction of the word through definitions in dictionaries, and through quotations from debates in the federal Constitutional Convention and in Congress. The appellant's brief in the Feigenspan Case (which bears Mr. Root's name) urged also that:

"The word 'amend' has a necessary relation to some particular thing which is to be amended. The word has no meaning whatever except in relation to that thing. The change for better or worse which is called an amendment must be a change in the particular thing amended. The necessary relation of amendment to the thing to be amended is ordinarily expressed by the rule that amendments must be germane."

These arguments were fully and effectively answered, both on the historical and other bases, by Mr. Hughes' briefs in the Rhode Island and the Kentucky Distilleries cases. Mr. Hughes shows that the word "amendment" was used generally in the debates and discussions of the time as equivalent to "alteration," and as permitting any changes which might be regarded as proper or desirable in the operation of the government being set up by the Constitution of $1787^{31}$

The most effective point made against this argument, however, is that the argument, even if admitted, would accomplish nothing so far as the Eighteenth Amendment is concerned. The Solicitor General's brief in the Feigenspan Case expresses the matter clearly when it says:

${ }^{\infty}$ At pp. 29,66 et seq. $\quad{ }^{\circ}$ At p. 37.

"Brief for the states in Kentucky Distilleries and Warehouse Company v. Gregory, at P. 4I, et seq.; and in State of Rhode Island v. Palmer, at p. 13, et seq. 
"But this amendment comes clearly within even the narrow definition suggested, as counsel say the original Constitution granted enlarged powers to the government and distributed those powers and directed how they should be exercised, and imposed limitations both upon the powers granted to the federal government and the powers reserved to the states. In so far as this amendment confers additional powers of legislation upon Congress, it follows in the footsteps of the framers of the Constitution by granting enlarged powers to the federal government. In so far as the powers thus granted are taken from the states, it merely operates to change the original distribution of power."32

And the brief correctly adds in its further discussion that:

"In the very nature of things almost any amendment that could be adopted would take either from the states or the federal government some of the powers belonging to them respectively."

Mr. Hughes sums up the matter perhaps even more clearly when he says that

"nothing could be more in consonance with a plan for the amendment of the constitution than provision for a change in the distribution of powers, either by subtracting from those conferred upon the federal government or by taking some part of that which had been reserved and giving it to the federal government." ${ }^{33}$

Another argument based upon the word "amendment" is that presented by the appellant's brief in the Feigenspan Case. Here counsel argued that the Eighteenth Amendment is in effect legislation, in that it lays down a rule operative upon the states and upon individuals without the necessity for congressional legislation, and that such an amendment, being legislation, is not within the express power conferred upon Congress by Article 5 of the Constitution. It will be well to quote the language of the brief, which bears Mr. Root's name:

"Our contention is not for a further exception to the power granted; it is that the grant itself does not include the power of ordinary legislation. This is no more affected by the fact that there are express exceptions to the power which was granted than would be the proposition that the grant of the Fifth Article does not include the judicial power or power to command the army and navy."1s4

The point under contention is made perhaps even clearer by another statement in this brief :

"In this respect a constitutional amendment granting to the government power to prohibit intoxicants would be quite different from an

\footnotetext{
${ }^{2}$ At pp. 34,35 and 48 .

"Brief for the states in Kentucky Distilleries and Warehouse Company $v$. Gregory, at p. 40 .

"At p. 16.
} 
attempted amendment itself directly declaring the prohibition of intoxicants. The former would merely add to the powers of government and would, therefore, in this regard at least, be a proper form of constitutional amendment; while the latter in its essence neither would add nor withdraw powers of government, but would be direct legislation. The Eighteenth Amendment is, therefore, in substance and effect a statute, not a constitutional provision akin to any in the federal Constitution."

It is sought to bolster up this argument by the provision of the Constitution vesting all legislative power in Congress; and to sustain it further by the purely political argument that legislation thus embodied in the Constitution becomes permanent and beyond the control of the majority, because of the fact that change may be prevented by fourteen states containing only a very small minority of the population of the country ${ }^{35}$ A similar argument will be found in an article which recently appeared in the Harvard Law Review. ${ }^{36}$

This argument might be termed somewhat ridiculous, had it not appeared under the distinguished name of Mr. Elihu Root. The Solicitor General's brief in the Feigenspan Case reviews a number of provisions of the original Constitution and of amendments thereto before the Eighteenth Amendment, and properly says:

"That the provisions referred to are acts of legislation in the sense that they establish rules of law can not be doubted. They and other provisions constitute a body of laws which the framers of the Constitution deemed of such importance that they should be enacted and placed beyond the control of any branch of the government." ${ }^{37}$

Mr. Hughes' brief in the Kentucky Distilleries Case presents the situation even more vigorously:

"And what is 'legislation' which is thus said to lie outside the scope of the amending power according to the theory presented? Is it that the amendment must not be self-executing? But the obvious answer is that the Thirteenth Amendment is self-executing and it has been so adjudged by this court. . . . .

"Is it that the amendment must not directly affect the rights of persons without the intervention of legislation? The Thirteenth Amendment did that, for it made free men out of slaves.

"Is it that the amendment must not directly disturb without further legislation vested rights of property? But the Thirteenth Amendment destroyed property in slaves.

"The attempt is made to explain in some way that the Thirteenth

${ }^{23} \mathrm{pp} . \mathrm{II}, \mathrm{I} 4$ et seq., 48.

${ }^{30}$ William L. Marbury, The Limitations upon the Amending Power (Igrg) 33 HARv. L. Rev. 223. See a reply to this article by William L. Frierson, Amending the Constitution of the United States: A Reply to Mr. Marbury (1920) 33 HARv. L. REv. 659. Mr. Frierson's name will also be found signed to the brief for the appellees in the case of Feigenspan $v$. Bodine.

"At p. 37. 
Amendment, which did all these things, was not legislation. It is impossible then to understand in what sense the term "legislation' is used. For that which establishes a rule of law which, being selfexecuting, determines without further legislation the rights and status of persons and rights of property manifestly has the direct operation and effect of legisiation."

Mr. Root's brief refers to the case of State ex rel. Halliburton $v$. Roach, ${ }^{39}$ but does not seek to make much use of this case, and it is doubtful whether the full facts of the case would have aided the contention being made. The court in the Roach Case took the view that it was improper to propose by initiative petition an amendment to the constitution of Missouri providing for the redistricting of the state for the election of state senators. The original constitution of the state provided for senatorial districts, but the original provision had long ceased to be in force because the power to redistrict had, by other provisions of the constitution, been conferred upon and exercised by the state legislature. The court, by a bare majority, said that

"the petitioners have no right to undertake to put in the constitution, which is regarded as the organic and permanent law of the state, mere legislative acts providing for the exercise of certain powers."

The decision was pretty clearly a political one for the purpose of maintaining an existing apportionment, and there is no satisfactory authority in support of the view that the court may determine what the amending power in a state shall place within the text of a state constitution. The Roach Case is further weakened by the fact that the language there sought to be embodied in an amendment was of the same type as provisions which will be found in practically every constitution framed by a constitutional convention.

For a court to pass upon the propriety of placing a matter in a constitution, either state or federal (except as expressly provided by the language of the constitution itself), would deny the people and the amending process any authority to place in the constitution anything which the court might itself regard as not properly belonging in the text of a constitution, and would introduce into American constitutional practice a highly undesirable type of judicial control.

In the brief of the state of Rhode Island and in Mr. Root's brief for appellants in the Feigenspan Case, it is urged that the nature of

At pp. 5I+52.

(1910) 230 Mo. 408, 130 S. W. 689. State v. Keith (1869) 63 N. C. 140, and Eason v. State (185I) II Ark 48I, were referred to in the briefs against the Amendment as sustaining the view sought to be supported also by State ex rel. Halliburton $v$. Roach, but these cases do not seem to be capable of such a use State $v$. Keith says that a state constitutional convention is limited by the Constitution of the United States. Eason $v$. State finds a state constitutional limitation to be applicable in its terms to the legislative proposal of specific state constitutional amendments. 
the federal system in some manner forbids constitutional amendments changing the distribution of powers as between the states and the United States and reducing the states' police power. Mr. Root's brief sums up this argument as follows:

"There can be no reasonable doubt, that it was contemplated by the framers, and is implied in the Constitution itself, that the several states, then existing or thereafter to be created, should be sovereign and autonomous in their spheres of local self-government. Hence any amendment which impairs or tends directly to destroy the right and power of the several states to local self-government should be held void as in conflict with the intent and spirit and implied limitations of the federal Constitution adopted by the people of the United States." 10

A similar view is expressed in the brief of the state of Rhode Island:

"Congress may not constitutionally propose, therefore, nor may the legislature of a state constitutionally ratify any proposition as an amendment that involves the exercise or the relinquishment of the sovereign powers of a state."41

The historical arguments presented in support of this contention were poor, and the whole argument is chiefly one that the amending process is not to be interpreted as unlimited, because if unlimited it might at some time be unwisely employed. A complete answer will be found in Mr. Hughes' briefs in the cases of Rhode Island $v$. Palmer ${ }^{42}$ and Kentucky Distilleries and Warehouse Company $v$. Gregory. ${ }^{43}$

In so far as the contention against the Amendment was based upon the claim that the national government may not interfere with the states' police power, it was perhaps sufficiently met by the fact that the Constitutional Convention of 1787 expressly rejected a proposed limitation upon the amending clause "that no state shall without its consent be affected in its internal police." Upon principle, however, there seems to be little, if any, basis for a notion that the state is completely in the possession of the police power, and that in some manner the nature of the federal system guarantees this police power of the state against reduction or impairment. The term "police power" is ordinarily employed to define a governmental power to control in a certain manner, and such a power belongs to the government which may exercise such a type of control. If "police power" is defined as the state's power to control (and this definition is implied in the briefs against the Eighteenth Amendment), such power becomes by definition ex-

\footnotetext{
${ }^{\infty}$ At p. 65 .

"At p. r20. For a full statement of this contention see the brief of the state of Rhode Island, at p. 37 et seq.

At p. 34 et seq.

"At p. 39. See also, D. O. McGovney, Is the Eighteenth Amendment Void Because of Its Contents? (1920) 20 CoL. L. REv. 499.
} 
clusively a state power, and does not include similar national powers of control which result expressly or impliedly from the powers granted to Congress by the United States Constitution. There is, of course, no federal police power independently of the things which the Constitution authorizes Congress to do, just as there is no other federal power independently of the powers conferred by the federal Constitution. The argument that the police power is a state power is merely a play upon words. General police authority belongs to the state, because it relates primarily to matters not granted to the United States, but the general police power of the state yields to federal power in the same field where the national government has authority to act. This is not a statement that the police power is exclusively a state power, for police authority is to a large extent exercised by Congress through commerce, postal, taxing, and other powers. Clearly there is no implication of any sort that police powers belong exclusively to the states, and may not be altered by the federal amending power. The arguments frequently made in the briefs that the two governments move in distinct spheres, and that the federal government has no police power, have long been untrue, if they were ever well founded. The argument that the United States has no police power is true only to the extent that it has no powers except such as are granted to it.

An argument somewhat similar to that just referred to appears frequently throughout the briefs, that certain principles of the Constitution are unamendable and are to be read as limitations of the amending article. This view appears frequently in Mr. Root's brief in the Feigenspan Case. Several quotations from this brief will present his attitude more clearly:

"It is inconceivable that both the nation and the states may to all practical intents have their fundamental characters changed or destroyed whenever it pleases two-thirds of the houses of Congress, and threefourths of the legislatures of the states, which latter may readily represent only a minority of all the people of the United States. The possibility of any such outcome should condemn any rule that would permit it."

And again :

"Thus, the provision guaranteeing due process of law is plainly so vital to free government that it may not be destroyed, but the provision against self-incrimination or indictment by a grand jury may well be regarded as standing on a different footing." $\$$

Similar to this is the view expressed in several parts of Mr. Root's brief, and the view expressed by Messrs. Mayer and Bullitt in their brief in the Kentucky Distilleries Case, that the Ninth and Tenth Amendments became by adoption limitations applicable to all of the terms of the original Constitution and as such unamendable. The

"At pp. $92,98$. 
brief of Messrs. Mayer and Bullitt in the Kentucky Distilleries Case says that:

"The powers reserved by the Ninth and Tenth Amendments are powers reserved from the operation of Article 5 as well as from the operation of any other articles of the Constitution."45

Mr. George Ticknor Curtis' discussion in his Constitutional History of the United States appears to be the primary source of these arguments of Mr. Mayer and Mr. Root, and also of the general arguments based upon the nature of the federal system. ${ }^{46}$

The whole argument that the amending process is limited by amendments adopted through such process is sufficiently disposed of by Mr. Hughes' brief in the case of State of Rhode Island v. Palmer:

"Article 5 itself was not amended. And, not being amended, Article 5 stood as effective with respect to the manner in which future amendments might be obtained as it had been prior to the adoption of the first ten amendments. These ten amendments themselves, by virtue of the fact that they were amendments, became part of the Constitution and thus became subject to the amending power contained in Article 5 equally with any other part of the Constitution."

Appellant's brief in the Feigenspan Case apparently takes the view that a convention called under the terms of Article 5 of the Constitution would have greater power than Congress has in the proposal of amendments, although it is difficult to see the basis for such an argument, because the constitutional power confersed is the same as to the two methods of alteration. In this brief, however, the statement is made that:

"If fundamental changes become necessary, a convention may be called on the application of two-thirds of the states for that purpose. ... It does not, however, by any means follow that the same unrestrained power is vested in their governmental agents, that is, in twothirds of the houses of Congress and the legislatures of three-fourths of the states." 48

In the case of Rhode Island v. Palmer, the Supreme Court merely says:

"At pp. 13, 15. See also, oral argument of Levy Mayer, at p. 15. The same views will be found suggested in Mr. Root's brief for the appellant in the Feigenspan Case, at pp. 9I, 92.

" The same line of argument will be found in George D. Skinner, Intrinsic Limitations on the Power of Constitutional Amendment (Ig20) 18 MrcH. L. REv. 213. A contention somewhat similar in character is that made in the brief of appellant in the case of Kentucky Distilleries and Warehouse Company $v$. Gregory, that the Eighteenth Amendment is subject to the provisions of the Fifth Amendment. The argument here is not one as to the constitutionality of the Eighteenth Amendment, however, but is an argument that the Eighteenth Amendment should be construed as subject to the principle laid down in the Fifth Amendment.

"At p. 35

At pp. 68, 69. 
"4. The prohibition of the manufacture, sale, transportation, importation, and exportation of intoxicating liquors for beverage purposes, as embodied in the Eighteenth Amendment, is within the power to amend reserved by Article 5 of the Constitution.

"5. That Amendment by lawful proposal and ratification has become a part of the Constitution, and must be respected and given effect the same as other provisions of that instrument."

In stating these views the Court has necessarily rejected substantially all of the arguments presented in favor of implied limitations upon the federal amending power, although its statement does not necessarily go to the extent of denying all limitations other than those clearly expressed in the constitutional language itself. The Supreme Court of the United States has at practically all times been liberal in its construction of national powers, and has been unwilling to adopt principles by which limitations upon such powers are implied.9 Every argument of law and policy favors the view that the Court should not read into the amending power limitations not within the constitutional language.

Within the constitutional limits the question as to what amendments shall be proposed and adopted, either to the federal Constitution or to state constitutions, is pretty clearly not a proper question for the courts, but to have construed the word "amendment" in a narrow manner or to have adopted other implications urged by those opposing the Eighteenth Amendment, not only would have narrowed the use of the amending clause, but would have left the question of amending power in each case to judicial decision without the guidance of any legal principle. The determination of what was or what was not an amendment under such a plan would become, just as in the Missouri case of State ex rel. Halliburton $v$. Roach, a question which could be determined only upon the basis of considerations not clearly legal in character. The Solicitor General's brief in the Feigenspan Case was clearly right, both in law and in fact, when it said that

"the Congress itself and the ratifying legislatures have been made the judges of whether a proposed amendment is germane and their decision is final.",50

This does not mean in any way that the Court may not pass upon the limitations imposed by the Constitution, but it does mean that the Court properly took the view that no implications should be constructed by which a court itself should decide upon the propriety of each proposed amendment.

Another valid objection to such a broad view as that urged by those opposed to the Eighteenth Amendment is well expressed by $\mathrm{Mr}$. Hughes in his brief in the Rhode Island Case:

\footnotetext{
-See article on Implied Powers and Implied Limitations in Constitutional Lazw (rg19) 29 YALE LAw JouRNaL, I37.

- At p. 42.
} 
"Such restrictions, established by judicial decree, could not be removed by any process of constitutional amendment which the Constitution affords. As such restrictions would affect the power of amendment, they could not be eliminated by amendment. They would remain unalterable except by the Court itself unless in some manner a new constitution were adopted outside the exercise of amending power contained in the present Constitution."

This view of Mr. Hughes is reiterated in the brief which he presented in the case of the Kentucky Distilleries and Warehouse Company, where he again urges that judicial constructions have always been open to change through constitutional amendment, but that for the Court to limit the amending power itself would constitute a constitutional change beyond the reach of popular control. ${ }^{52}$

Ratification by state legislatures. Another important question in connection with the amending process is that as to the power of Congress to regulate the exercise of this power. The amending power conferred by Article 5 of the Constitution is pretty clearly a power vested by the Constitution in the government of the United States, and Congress has authority "to make all laws which shall be necessary and proper" for the exercise of such a power. The power is one belonging to the government of the United States, of which the states are a part for the purpose of ratification. It is clear, therefore, that Congress has the authority to enact such legislation as that of 1818 , making it the duty of the Secretary of State to cause amendments to be promulgated whenever official notice has been received that proposed amendments have been adopted in accordance with the provisions of the Constitution.

In proposing the Eighteenth Amendment, Congress provided that the amendment should be "inoperative unless it shall have been ratified as an amendment to the Constitution by the legislatures of the several states as provided in the Constitution within seven years from the date of the submission hereof to the states by the Congress." No constitutional objections to the Eighteenth Amendment were urged because of this provision, although in I9I9 a proposed constitutional amendment was favorably reported upon in the United States Senate which limited the ratification of federal amendments to "six years from the date of their proposal." This amendment had been proposed by Senator Brandegee, and the need for the amendment was suggested by Senators Brandegee, Ashurst, and Borah, on the ground that a congressional limitation of this type was probably unconstitutional. ${ }^{\text {ss }}$

"At p. 30.

" Cong. Rec. (66th Cong., Ist sess.) 5694-5700; id. (65th Cong., $2 d$ sess.) 477; id. (65th Cong., Ist sess.) 5556-5558. Senator Borah suggested the probable unconstitutionality also of the provision that the amendment if adopted should become operative one year after its ratification. 
It would seem that congressional legislation may properly be enacted limiting to a reasonable period after submission the power to ratify a proposed amendment to the federal Constitution. Jameson, however, took the opposite view and said:

"No power is granted to prescribe conditions as to the time within which the amendments are to be ratified, and hence to do so would be to transcend the power given. The practice of Congress in such cases has always conformed to the implied limitations of the Constitution. ${ }^{54}$

Jameson's statement of fact correctly applies to all constitutional amendments proposed before the Eighteenth Amendment. Jameson, however, did take the view that some limitation is desirable, and suggested that a constitutional amendment for the purpose be adopted. Even if Congress were not constitutionally empowered to impose such a limitation, it is probable that the courts would almost of necessity take the view that the proposal of an amendment without an express limitation of time does not keep such proposal indefinitely before the states. In 1873 , the senate of Ohio adopted a joint resolution ratifying the second of the twelve amendments submitted to the states by Congress in $1789 . .^{35}$ In 1789 the states numbered thirteen; in 1873 they numbered thirty-eight. It is quite certain that a sufficient number of states would not begin ratifying in 1873 to cause the adoption of an amendment proposed in 1789 , but the situation presented is not altogether satisfactory in character.

The Eighteenth Amendment placed in the text of the amendment itself the language postponing its application to one year after ratification thereof, and also the language providing that ratification must take place within seven years from the date of submission. It is clearly a proper part of a constitutional amendment to prescribe when it shall take effect, although it is more doubtful whether the provisions of a proposed amendment should contain conditions as to the ratification of that amendment. Clearly if Congress has no power to impose a limit upon the period of ratification, it would have no power to accomplish the same purpose by embodying such a limitation in the proposal itself, so that the state legislatures must either accept the limitation or decline to ratify. However, it is believed that Congress has constitutional power to impose a time limitation upon the ratification of amendments.

The power to fix a time limit within which an amendment shall be ratified is not the same as a power to recall an amendment when once it has been submitted. The function of the two houses of Congress is that of submitting an amendment, and when they have done this their power with respect to that amendment may be said to be functus officio. Power has then passed from Congress to the states, and a

\footnotetext{
"Jameson, 634
}

Jameson, 635; Ames, 29r. 
reconsideration by Congress at a later period may not destroy the action which states may have already taken, or prevent subsequent state action.

To what extent may Congress regulate the procedure of state legislatures in passing upon a proposed constitutional amendment? The state legislatures in passing upon a constitutional amendment may properly be said to act as organs of the national government rather than as state agencies, and if a congressional regulation were necessary and proper, it could be enacted. However, it is clear that the state legislatures are not subject to congressional control as to what they shall do. In 1866 when the Fourteenth Amendment was under consideration in the United States Senate a resolution was proposed that this amendment should be submitted to legislatures which should be chosen, or the members of the most popular branch of which should be chosen, next after the submission of the amendment, at the first session thereof. Several other proposals of a similar character were presented but such proposals were defeated, largely on the ground that they were in violation of the United States Constitution. In I869 a resolution was proposed in the United States Senate prescribing the rules to be followed by state legislatures in passing upon constitutional amendments. ${ }^{58}$ It is probably beyond the power of Congr $\because s$ to determine the dates upon which such legislatures shall consider proposed constitutional amendments, or to prescribe the requisite vote in a state legislature for the ratifications of a proposed amendment. These were the things attempted by the Senate proposals of 1869 . Clearly no federal legislation may impose conditions or restrictions upon the method of ratification by state legislatures, although the period within which ratifications may be had is probably within congressional control. A reasoriable limitation upon the period for ratification may be appropriate as an incident to the purely congressional power of proposing amendments, although it to some extent restricts the complete freedom of state ratification; but it does not restrict the free will of the state legislature in acting on the proposal, or limit the state's determination as to the organization of its representative legislature. The act of ratifying is a federal function, but the legislature doing the act is the state legislature.

Upon the subject of state ratification, the question most vigorously argued in the recent Eighteenth Amendment cases was that as to what are "state legislatures." The argument was vigorously urged that the term "legislatures" as used in Article 5 of the Constitution signifies "not solely the legislative assembly of a state, but the repository of legislative power therein."'57 The same view was urged in the brief of appellant in the Kentucky Distilleries Case, where it is suggested that "clearly it was intended that the ratification should

- Ames, 287-20r.

"Brief for appellant in Feigerspan v. Bodire, at p. 120. 
be by the legislative power of the states as distinguished from the judicial and executive." In view of this argument it was urged that in the states where a referendum had been adopted, such referendum was one means of exercising legislative power and might be made applicable to federal constitutional amendments. It was said that this referendum constituted a part of the state ratifying machinery. Mr. Root's brief went so far as to suggest that if a state had once adopted a referendum, this referendum became a part of the state legislature, and that if the state had not made such a referendum applicable to federal amendments, there existed no legislative power in the state capable of action upon such proposed amendments. ${ }^{58}$ This view is perhaps logical, for if a state had adopted the referendum, and if the referendum were to be treated as a part of the state legislature, it is difficult to see how there could be state legislative ratification without the possibility of using the referendum. If the referendum in its terms were therefore not applicable to federal amendments, Mr. Root might logically urge that there was no authority in that state capable of ratifying a federal amendment.

The arguments for an interpretation of the word "legislature" so as to include "referendum," were effectively met by Mr. Hughes's brief in the Kentucky Distilleries Case. Mr. Hughes properly calls attention to the fact that proposals for popular ratification of federal amendments were actually made in $186 \mathrm{I}$ and 1869 , and that the term "legislature" as used in the constitution is in all cases employed as relating to a representative body. ${ }^{50} \mathrm{He}$ might have added further that the Constitution by its terms provides for ratification either by state legislatures or by conventions in the several states, and that both methods clearly contemplate action through representative bodies rather than through popular voting.

Attention may perhaps properly be called to the fact that in recent years, a number of proposals have been made for the ratification of federal constitutional amendments by popular vote in the several states, and in I919 a proposal was debated in the United States Senate which provided that Congress might specify ratification by electors in the several states as an alternative to ratification by legislatures or by conventions. 0

In the case of Hawke v. Smith, the Supreme Court settled the issue as to what constitutes the "legislature" of a state for the purpose of ratification. The court said:

"The only question really for determination is: What did the framers of the Constitution mean in requiring ratifications by 'legislatures'? That was not a term of uncertain meaning when incorporated into the

"Brief for appellant in Feigenspan v. Bodine, at pp. 1r5-117.

- At pp. 24-34.

- Cong. Rec. (66th Cong., Ist sess.) 5694-5700. For a review of earlier efforts to obtain ratifications by popular vote, see Ames, 293-294. 
Constitution. What it meant when adopted it still means for the purpose of interpretation. A legislature was then the representative body which made the laws of the people. The term is often used in the Constitution with this evident meaning. Article I, section 2, prescribes the qualifications of electors of Congressmen as 'those requisite for electors of the most numerous branch of the state legislature.' Article I, section 3, provided that Senators shall be chosen in each state by the legislature thereof, and this was the method of choosing Senators until the adoption of the Seventeenth Amendment, which made provision for the election of Senators by vote of the people, the electors to have the qualifications requisite for electors of the most numerous branch of the state legislature. That Congress and the states understood that this election by the people was entirely distinct from legislative action is shown by the provision of the amendment giving the legislature of any state the power to authorize the executive to make temporary appointments until the people shall fill the vacancies by election. It was never suggested so far as we are aware, that the purpose of making the office of Senator elective by the people could be accomplished by a referendum vote. The necessity of the amendment to accomplish the purpose of popular election is shown in the adoption of the amendment. In Article IV the United States is required to protect every state against domestic violence upon application of the legislature, or the executive when the legislature cannot be convened. Article VI requires the members of the several legislatures to be bound by oath, or affirmation, to support the Constitution of the United States. By Article I, section 8, Congress is given exclusive jurisdiction over all places purchased by the consent of the legislature of the state in which the same shall be. Article IV, section 3, provides that no new states shall be carved out of old states without the consent of the legislatures of the states concerned.

"There can be no question that the framers of the Constitution clearly understood and carefully used the terms in which that instrument referred to the action of the legislatures of the States. When they intended that direct action by the people should be had they were no less accurate in the use of apt phraseology to carry out such purpose. The members of the House of Representatives were required to be chosen by the people of the several states. Article I, section 2.

"It is true that the power to legislate in the enactment of the laws of a state is derived from the people of the state. But the power to ratify a proposed amendment to the federal Constitution has its source in the federal Constitution. The act of ratification by the state derives its authority from the federal Constitution to which the state and its people have alike assented. . . . Any other view might lead to endless confusion in the manner of ratification of federal amendments. The choice of means of ratification was wisely withheld from conflicting action in the several states."'11

\footnotetext{
- The Court readily distinguished the view in this case from that taken in State of Ohio ex rel. Davis v. Hildebrant (1916) 241 U. S. 565,36 Sup. Ct. 708. See also Ex parte Dillon (1920, N. D. Calif.) 262 Fed. 563 ; and article by W. H. Taft, Can Ratification of an Amendment to the Constitution Be Made to Depend on a Referendum? (1920) 29 YALE LAW JoURNar, 821. In view of the decision of the United States Supreme Court regarding state referenda upon proposed amendments to the federal Constitution, little attention need be given to the decisions of state courts with respect to the application of the state
} 
The case of Hazke v. Smith arose under an Ohio constitutional amendment which expressly provides that the action of the legislature in ratifying a proposed federal amendment shall be subject to the referendum. The Court said as to such a state requirement:

"The argument to support the power of the state to require the approval by the people of the state of the ratification of amendments to the federal Constitution through the medium of a referendum rests upon the proposition that the federal Constitution requires ratification by the legislative action of the states through the medium provided at the time of the proposed approval of an amendment. This argument is fallacious in this-ratification by a state of a constitutional amendment is not an act of legislation within the proper sense of the word. It is but the expression of the assent of the state to a proposed amendment."

The view taken by the Court clearly makes it improper for a state constitution to impose limitations upon the exercise by the legislature uf its power to ratify a federal constitutional amendment. If a state may not require a referendum, nor impose conditions upon the exercise of the power of the state legislature as a federal agency, clearly there is no power in the state to impose the condition now found in the constitution of Missouri that "the legislature is not authorized to adopt nor will the people of this state ever assent to any amendment or change of the Constitution of the United States which may in any wise impair the right of local self-government belonging to the people of this state."'sz Clearly, also, a state constitution has no authority to impose the limitations found in the constitutions of Florida and Tennessee, that no convention or legislature of the state shall act upon any amendment to the Constitution of the United States, unless such convention or legislature shall have been elected after the amendment is submitted. ${ }^{\text {ss }}$

It should be remembered, however, that ratification is by state legislatures, and that although the state may not provide any other

referendum to federal amendments. Decisions holding state referenda applicable to the federal amending process are Hawke v. Smith (19r9, Ohio) i26 N. E. 400 (reversed by the United States Supreme Court); State v. Howell (1919, Wash.) 18I Pac. 920; State v. Amsberry (1919, D. C. Lancaster County, Neb.); Carson v. Sullivan (19r9, C. C. Cole County, Mo.). A contrary view as to the state referendum was taken in the Opinion of the Justices (1919, Me.) rog Ati. 673;. Herbring v. Brown (1919) 92 Ore. 176, 180 Pac. 328; Whittemore v. Terral (1919, Ark) 215 S. W. 686; Prior v. Noland (1920, Colo.) 188 Pac. 729; Barlotti v. Lyons (I920, Calif.) I89 Pac. 282; and Decher v. Vaughan (I920, Mich.) 177 N. W. 388 . State v. Morris (I920, Okla) I91 Pac. 364, and Carson v. Sullivan (1920, Mo.) rgr Pac. 571, were decided after the decision of Hawke v. Smith in the Supreme Court. Ohio was the only state having a constitutional provision expressly providing for the use of the referendum upon proposed federal amendments."

' Const. of Mo. (1875) Art. 2, sec. 3.

" Const. of Fla. (1885) Art. 16, sec. r9; Const. of Tenn. (1870) Art. 2, sec. 32 
method of ratification or impose limitations upon the power to ratify, it does seem to be clearly within the power of the state through its constitution or otherwise to determine what shall be the organization of the state's representative legislative body, and what shall be the quorum for action by that body. It, of course, also rests within the power of the state itself as to when regular or special sessions of the state's representative body shall meet, and as to how that representative body shall be organized. The brief for appellant in the Kentucky Distilleries Case urged that the states by abolishing a representative legislative body might destroy the possibility of future amendments to the Constitution, except so far as ratification may be provided by conventions. This argument is based upon too remote a possibility to have much weight, and even assuming that representative state legislatures should disappear, the federal amending process would still be capable of effective operation through congressional provision for ratification by conventions in the several states.

An issue which presents itself with respect to state ratifications is that as to whether the governor has any veto power over the state legislative action in this regard. It has already been suggested that the President of the United States has no power to disapprove the action of Congress in proposing constitutional amendments to the states, and this view is taken because the proposal of constitutional amendments is not regarded as a regular function of legislation, the Constitution prescribing it as a different process to be exercised in a different manner. The same view applies with respect to the governor's power of vetoing the state legislative ratification of a federal amendment. The state legislature here is not acting as a state legislative body under the terms of the state constitution, but is, in the clear view expressed by the Supreme Court, acting as an agent of the national government in the performance of a function specified by the Constitution of the United States. The governor has, by the terms of the federal Constitution, no share in this function. The governor of New Hampshire vetoed the resolution of the legislature of that state ratifying the Twelfth Amendment, but as the vote of the state was not needed to make up the three-fourths vote required for the ratification of the amendment, no issue seems to have been made about the matter..$^{84}$ When the legislature of the state of Kentucky rejected the Thirteenth Amendment, the resolution was presented to the governor of that state. The governor, although disagreeing with the legislative action, merely transmitted the action of the general assembly to the federal authorities. ${ }^{65}$ When the income tax amendment was pending, Mr. Hughes, who was then governor of New York, sent a message to the legislature of that state recommending that the amendment be not approved, but nothing in the circumstances indicated any view upon his part that he had any negative power over

"Ames, 297.

${ }^{\infty 5}$ Ames, 297; Jameson, 630. 
such action as might be taken by the legislature. In the state of Arkansas, the legislative action ratifying the income tax amendment was submitted to the governor and was vetoed by him. The action of the legislature was, however, transmitted to the Secretary of State of the United States, and Arkansas was properly counted as one of the states ratifying that amendment. ${ }^{\circ 6}$

What constitutes ratification by a state? Clearly a constitutional amendment is submitted to the state without conditions, and no state can ratify conditionally. Such a ratification is merely equivalent to a rejection or failure to ratify.

The question has presented itself several times as to whether a state which has once ratified may withdraw its ratification of a federal amendment. The states of New Jersey, Ohio, and Oregon, after giving their consent to the Fourteenth Amendment, -sought to withdraw this consent; ${ }^{67}$ and the state of New York sought to withdraw its consent to the Fifteenth Amendment. ${ }^{68}$ Jameson takes the view, and the view is incontrovertible, that a state, once having ratified, may not withdraw that ratification. He suggests that to construe the Constitution otherwise, would be to permit great confusion in that no state in ratifying could know what the status of the amendment was if at the same time other states were permitted to withdraw. Of course, confusion would occur also in that it would be difficult to know when three-fourths of the states had ratified. Clearly, no state could be permitted to withdraw after three-fourths had ratified and adhered to their ratification. The function of ratification seems to be one which, when once done, is fully completed, and leaves no power whatever in the hands of the state legislature. This is the view taken in connection with the Fourteenth Amendment. In the case of the Fourteenth Amendment, the Secretary of State of the United States issued a certificate in which he declared the amendment adopted, provided the ratifications of New Jersey and Ohio were to be considered as still valid. On the following day a concurrent resolution was passed by Congress pronouncing the ratification of the amendment valid and sufficient. ${ }^{82}$ As Jameson says, Congress has definitely taken the view in this instance that a state once having ratified may not withdraw its ratification of a federal amendment. This view seems clearly a correct one. The recent action in Tennessee on the woman suffrage amendment presents the latest case of an attempt to withdraw ratification.

\footnotetext{
* The Department of State has on several other occasions taken the view that the governor has no power with respect to the state's ratification. In all of the states in which the issue has arisen, the view has been taken that the proposal of state constitutional amendments is not subject to the veto power of the governor. See discussion in my book, The Revision and Amendment of State Constitutions (1910) $148-152$.

$\pi$ The state of Oregon did not withdraw her consent until after the adoption of the amendment.

- Ames, 299; Jameson, 631. Jameson, 628-633.
} 
On the other hand, it is perhaps clear that a state legislature has a continuing power of ratification until an amendment is adopted, or until such a long period has elapsed that a sort of statute of limitations may be said to have run against any power to ratify the proposal. It may be remembered that the power in the state legislature is one derived from the federal Constitution, and is a power to ratify, not a power to reject. If a constitutional amendment is proposed, one state legislative session may not by explicitly rejecting prevent the further exercise of the federal power conferred upon the state legislature. Rejection by a state legislature is in this respect equivalent to the negative result arising from state legislative inaction. There is no power in and of itself to reject a federal constitutional amendment, and failure to act by one-fourth of the states is sufficient. In the case of the Thirteenth Amendment, New Jersey first rejected the amendment and then ratified. In the case of the Fourteenth Amendment, four states (North Carolina, South Carolina, Georgia, and Virginia) rejected and then ratified. In the case of the Fifteenth Amendment, Ohio and New Jersey rejected and then ratified. In all of these cases, where the action was taken previous to the issuance of the proclamation that an amendment had been adopted, the states were included by the Secretary of State as ratifying. ${ }^{70}$

The question presented itself in connection with the adoption of the Thirteenth Amendment as to what constitutes three-fourths of the states. Several of the states counted in the ratification of that amendment had not been readmitted to representation in Congress, and a question was raised as to whether they could give valid assent to an amendment. In the case of the Fourteenth and Fifteenth Amendments ratification by a sufficient number of states was obtained by requiring approval of one or both of the amendments as a condition precedent to the admission of representatives to the federal Congress, from the states which had recently been in rebellion.

When an amendment is pending for some time before it obtains ratification, the number of states may have increased, and it is quite clear that three-fourths of the number at the time of ratification is required, rather than three-fourths at the time of the proposal of the amendment. The ratification must be by three-fourths of the state legislatures, and such a ratification could not be had unless at the time of final adoption of the amendment three-fourths of the states then in the Union had agreed thereto. Jameson suggests a difficulty in the counting of three-fourths which would present itself were a state permitted to withdraw after it has once ratified an amendment. This difficulty might present itself when nearly three-fourths had ratified, for a campaign to obtain withdrawals of ratification might leave a proposed amendment in suspense even though a state had ratified, which would be sufficient to make the three-fourths had another

"Ames, 300; Jameson, 629-630. 
state not withdrawn. However, as has already been indicated, it is clear that a state may not withdraw its ratification.

The case of Hawke $v$. Smith lays down clearly the principle that the whole power of proposing and ratifying amendments to the Constitution of the United States has its source in that instrument. The states have no independent power with respect to the matter, except so far as it is expressed in the federal Constitution, and Congress has no power except so far as power is necessary and proper to carry out the authority so conferred.

In this discussion only incidental attention has been paid to the possible use of conventions for the amendment of the Constitution of the United States. Congress has authority to call a convention on the application of the legislatures of two-thirds of the states, and a number of states have in particular instances passed resolutions asking that such a convention be called. The issue of calling a federal constitutional convention has, however, not seriously presented itself. ${ }^{71}$ Efforts have several times been made to have proposed constitutional amendments submitted to conventions in the several states instead of to state legislatures, but such efforts have been unsuccessful. ${ }^{72}$ A curious case of convention ratification was the ratification of the so-called Corwin amendment, proposed in I86r, by the state constitutional convention in Illinois in 1862 . This amendment was proposed by Congress to the state legislatures, and a convention assembled for the purpose of revising a state constitution had no authority whatever to pass upon the proposed amendment, but the issue as to its action never presented itself, because the proposal received little attention.

Operation of the federal amending clause. Affirmatively, it is clear that the federal amending clause makes necessary the concurrence in sentiment both of the states and of the population of the states, in order to adopt an amendment to the Constitution. After an amendment is once proposed by the two houses of Congress, three-fourths of the states, having less than one-half of the population, may ratify such an amendment, but clearly sufficient protection is accorded to population by the requirement of two-thirds of the members of the House of Representatives to propose an amendment, and a further protection is accorded to the states by the requirement of a twothirds vote by the Senate. It is true, of course, that the two-thirds of each house required is but two-thirds of a quorum, and that an amendment might actually be approved by the House of Representatives through the action of members representing a minority of the people of the country, but in case of any issue in which the

\footnotetext{
"A review of efforts to call conventions before 1890 will be found in Ames, 28I-283.

"Ames, 286-287.
} 
larger states might be arrayed against the smaller, it may well be expected that all members of both houses would be present when so important a matter as a federal amendment is to be voted upon.

Looking at the matter from a negative standpoint, however, it is clear that a small number of smaller states may prevent an amendment to the Constitution of the United States, and that without any union among the smaller states for such a purpose a proposed amendment may be defeated, although it has in its favor a distinct preponderance of opinion not only in a majority of the states, but also upon the part of the great majority of the people of the country.

The senators from one more than one-third of the states may prevent the proposal of a federal constitutional amendment, and this fact places a negative upon such proposal in the hands of seventeen states, which might represent a very small proportion of the population of the country. ${ }^{73}$ After an amendment is once proposed, a small group of states has power more completely in its hands, for the ratification of an amendment may be prevented by thirteen states. Upon the basis of this fact, it was urgently contended in the briefs opposed to the Eighteenth Amendment that the prohibition of traffic in liquors was a matter of temporary or legislative policy being placed in the Constitution, and that placing it in the Constitution established a permanent control over this matter by a minority, inasmuch as more than onethird of the members of the House and Senate could prevent any proposal of amendment to change the existing policy, and thirteen out of forty-eight states could prevent the ratification of any such change. It is true, of course, that less than ten per cent of the population of the United States, living in thirteen states, may control the issue as to whether a constitutional change shall be made, but since the adoption of the federal Constitution there has never been a definite alignment in this country of the smaller states against the larger, and there is no likelihood that the smaller states will so unite. So, also, if the larger states had a greater power in the proposal and ratification of amendments, there would be practically no possibility of all the larger states, distributed as they are in different parts of the country, uniting against the states of smaller population, which are also so distributed.

As a matter of fact, it may be said that there is greater practical difficuity in obtaining the proposal of amendments than in obtaining their ratification. The four amendments proposed in recent years were ratified without material delay. Professor $\mathrm{H}$. V. Ames published in 1897 a complete review of the proposed amendments to the federal Constitution during the hundred year period from $r 789$ to I889. During this period fifteen amendments were adopted; and

"Since the popular election of United States Senators, Senators cannot be said to represent the state as a political organization quite as distinctly as they did when elected by state representative bodies. 
four other amendments were proposed by Congress to the states for ratification, but not adopted. The proposed amendments not adopted related to the apportionment of representatives (proposed in 1789 ); compensation of members of Congress (proposed in 1789 ); titles of nobility (proposed in 1810); and, a proposal prohibiting the abolition of slavery (proposed in I86I). The proposal in I86I came too late in the slavery struggle to receive any favorable action by the states; Two of the four proposals which failed of ratification (that on apportionment of representatives and that on titles of nobility), failed of adoption by only one state's ratification. During the same period eighteen proposed amendments were approved by one house but not by the other, nine by the Senate and nine by the House of Representatives. Since 1889 each amendment proposed by the two houses of Congress has been ratified by the states; but a number proposed by one house has failed in the other. Proposals for the popular election of Senators were a number of times agreed on by the House of Representatives but not by the Senate, before the final proposal of this amendment. It may be true, of course, and probably is, that many proposed amendments have failed in the two houses because of the knowledge that ratification by the states would be difficult if not impossible, but so far as the facts indicate, ratification of the amendments proposed has been less difficult than has been the proposal of amendments by the two houses. ${ }^{74}$

For years it has been contended with some show of reason that the federal amending process is too difficult. ${ }^{25}$ Proposals for the alteration and simplication of the amending process have been frequently made. A review of such proposals down through the year 1889 will be found in Ames' work on Proposed Amendments to the Constitution of the United States during the First Century of Its History, ${ }^{76}$ and in an unpublished continuation of Ames' study prepared by Jacob Tanger of Pennsylvania State College.

It may be worth while to review briefly the more important changes suggested in the federal amending process. Professor J. W. Burgess in his Political Science and Comparative Constitutional Law, published in 1893, suggested that a plan be adopted as follows: "Proposal of amendments by two successive Congresses, Senators and Representatives acting in joint assembly and resolving by simple majority vote; submission of proposals to the legislatures of the several states, these again acting in joint assembly and resolving by simple majority vote; assignment to each state of the same weight in the count of votes as in

\footnotetext{
"Ames, 300.

"See Ames, 300 et seq; Munroe Smith, Shall We Make Our Constitution Flexible? (I9II) 194 North AM. Rev. 657; J. David Thompson, The Amendment of the Federal Constitution, (1912) 3 Publications of the Academy of Political Science, No. 2.

"At pp. 292-293.
} 
a presidential election, and ratification of amendments by a simple majority of the state votes thus weighted." Professor Munroe Smith has suggested a plan somewhat different from this, as follows: "Proposal of amendments by the majority vote of' both houses in two successive Congresses; submission of such proposals to the legislatures of the several states or to conventions in the several states or directly to the voters in each of the states, as one or another of these modes of ratification may be proposed by Congress; and ratification of proposals by a majority of the states, provided that the ratifying states contain, according to the last preceding enumeration, a majority of the total population of all the states." Both of these plans diminish the apparent control by states, as such, over the amending process; but as has already been said, the participation of the states, as such, is really unnecessary for the protection of either the large or the small states. Both of these plans give, of course, a much greater degree of power to the states with the larger populations. The proposal of Professor Burgess leaves no decisive control even to a majority of the states, and departs materially from the federal principle in our system of government. The plan suggested by Professor Munroe Smith preserves the federal principle more completely, by providing not only for a separate vote in the Senate, but also by providing that the ratification of a proposed amendment shall be by a majority of the states as well as by a majority of the total population.

The more important general proposals recently made for a change in the method of amending the federal Constitution, are those of Senators Cummins, La Follette, and Owen. Senator Cummins proposed, in I9I3, that there be added to the present amending article of the Constitution the following language:

"Whenever the legislatures of sixteen states shall adopt resolutions proposing any amendment, and the same are certified to the President of the United States, or whenever fifteen per centum of the voters in twenty-four states present to the President petitions authenticated by the respective governors of the said states proposing any amendment, the President shall submit the same to the several states, and in either case any such amendment shall be valid to all intents and purposes as a part of the Constitution when ratified by two-thirds of the several states acting either by direct vote of the people or by the legislatures, as may be determined by state law: Provided, that no state, without its consent, shall be deprived of its equal suffrage in the Senate."

An adverse report upon this proposal was submitted by the Senate Committee on the Judiciary in 1914, and a minority report presented by seven members of the committee urged that an easier method of amendment was desirable, although only two members (Senators Cummins and Ashurst) agreed in approving Senator Cummins' proposal.

The proposal introduced in I9I3 by Senator $\mathrm{La}$ Follette reads as follows: 
"The Congress, whenever a majority of both houses shall propose amendments to this Constitution, or on the application of the legislatures of ten states, or on the application of ten states through the vote of a majority of the electors of each, voting upon the question of such application, shall propose amendments to this Constitution, to be submitted for ratification in each of the several states to the electors qualified to vote for the election of Representatives. And the vote shall be taken at the next ensuing election of Representatives in such manner as the Congress may prescribe. And if in a majority of the states a majority of the electors voting thereon approve any proposed amendment, and if a majority of all the electors voting thereon also approve any proposed amendment, it shall be valid to all intents and purposes as part of this Constitution."

In this form Senator La Follette's proposal is merely an addition to Article 5 of the Constitution.

Senator Owen has several times proposed in Congress a plan by which a majority of the members of both houses may propose amendments, or by which either house alone may propose an amendment if the other twice rejects the proposal. He would also permit proposal upon application of a majority of the state legislatures. For ratification, his proposal adopts the plan of submission to the voters directly, and adoption, if ratified by a majority of the voters, provided the amendment also receives a favorable vote in a majority of the congressional districts. This plan (just as that of Professor Burgess) to a large extent disregards the federal principle in the proposal and adoption of constitutional amendments.

In connection with proposals which attempt to reduce materially the share of Senators in the proposal of constitutional amendments, or which tend (as do the Burgess and Owen proposals) to destroy the equal share of each state in the proposal of amendments, the question presents itself as to whether there may not be a violation of the limitation that no state without its consent shall be deprived of its equal suffrage in the Senate.

The proposals referred to above contemplate a substantial change in the whole procedure for the amendment of the federal Constitution. Comment should properly be made regarding proposals which do not seek to go quite so far. Senator Brandegee has several times introduced a proposed amendment which permits Congress to submit an amendment for ratification either to the state legislatures or to state conventions, or to the electors in the several states. Senator Brandegee's proposal, which has been twice unanimously reported by the Senate Committee on the Judiciary, also limits state ratifications to six years from the date of the proposal of an amendment. ${ }^{77} \mathrm{Mr}$. Seba Eldridge has for a number of years been urging a change in the federal amending process by which the question of calling a

"Cong. Rec. (66th Cong., Ist sess.) 5694-5700. 
federal constitutional convention should be submitted each twenty years to the voters of the several states. This plan is copied from that in force in some states by which the question of calling a state constitutional convention is submitted at periodical intervals. ${ }^{78}$

A few years ago it was thought that the difficulties of amending the federal Constitution were insurmountable except in times of grave crises. Ten amendments had been added to the Constitution almost immediately after the federal government went into operation, but these amendments might really be termed a supplement to the original Constitution. The Eleventh and Twelfth Amendments were adopted without great difficulty. Then followed a period of more than sixty years (1804-1865) in which no amendment to the Constitution was proposed and ratified. The three war amendments were adopted in the short period between 1865 and 1870 , but their adoption came as a result of a grave national crisis, and the ratification of these amendments by the states was obtained in part by methods not available in ordinary times, and perhaps not appropriate at any time.

However, at the present time the difficulties of federal amendment do not appear quite so great as they did a few years ago, because of the fact that since Igog four amendments have been ratified. In the briefs against the Eighteenth Amendment, efforts were made to have the Supreme Court adopt further limitations upon the federal amending process than those clearly appearing in the Constitution itself, and the Court was urged to take such a view largely on account of the great dangers urged as existing now because of an easy amending process, but it did not take the view of those seeking to destroy the Prohibition Amendment.

The arguments for a more restricted amending process than that now appearing in the express language of the Constitution were, of course, arguments for the purpose of sustaining a particular view in order to destroy, if possible, the establishment of federal prohibition in the Constitution. These arguments should, therefore, not be treated too seriously.

However, it is true that the view as to the difficulty of amending the federal Constitution is now quite different from the view which existed ten or twelve years ago. This changed attitude has, to some extent, made the federal amending process easier, for a part of the difficulty, at least before the ratification of the Sixteenth Amendment, was due to the feeling that the amending machinery was unworkable rather than to the unworkability of that machinery. It should on the other hand

${ }^{73} \mathrm{New}$ Hampshire requires a vote of this character each seven years; Iowa each ten years; Michigan each sixteen years; Maryland, New York, and Ohio each twenty years. The Oklahoma constitution leaves to the legislature the discretion as to when such a question shall be submitted to the people, but requires the question to be submitted at least once in every twenty years. 
be borne in mind that the four amendments proposed in recent years have all been ones which involved neither political nor sectional issues. Moreover, all of these amendments have related to matters as to which, at the time of submission, a generally favorable view had been reached. This statement may be contradicted with respect to the Eighteenth Amendment regarding federal prohibition, but the statement here made relates to the view existing at the time of proposal and ratification, and not to any views which may develop as a result of dissatisfaction with the Amendment in its actual operation.

A serious question presents itself as to whether the federal amending process should be so easy as to permit the introduction into the Constitution of provisions which involve distinctly sectional or political issues. Clearly the federal Constitution performs a function different from that of the state constitutions, and should be less flexible than the state constitutions may properly be. The function of the federal Constitution is primarily that of drawing a line between national and state powers, and such a line should not be subject to frequent variations. It is true, of course, that the inflexibility of the federal Constitution has thrown upon the courts a greater burden than they would otherwise have had, and the courts have to a large extent, by construction, enlarged the powers once conferred upon the federal government. However, this judicial enlargement comes gradually, and the United States Supreme Court, in its function of preserving the balance between national and state powers, has on the whole performed its service efficiently and in a statesmanlike manner. The federal amending process should be easier, but in bringing about a change in the federal Constitution or in any other constitution, two elements must unite: (a) the sentiment of the people in favor of change, and particularly in favor of the specific change being urged; and (b) operation of the machinery for the purpose of effecting such a change. A real change in the federal amending process has already been accomplished through a change in the first of the two elements just referred to, in that the view has been broken down that the present amending machinery is substantially unworkable. The machinery itself may still need to be changed, but in changing it attention should be given to the peculiar function of the federal Constitution, and no change should be made of such a character as to bring about constant agitation for a change of the boundaries between national and state powers, and a frequent shifting of the line drawn by the Constitution between national and state authority in this country. 